\title{
ДИГИТАЛНА МУЗИКОЛОГИЈА
}

\section{Сажетак}

Музиколошки институт Српске академије наука и уметности у Београду основан је 1947. године. Прва је научна установа своје врсте у Србији и на подручју бивше Југославије. Институт је од почетка замишљен као средишње место за музиколошка и етномузиколошка истраживања у Србији. Стога су као пратеће јединице постепено формиране Библиотека и архивска збирка. Институт поседује више од десет хиљада књига. Њихов тематски распон велик је: историја и теорија музике, црквена музика, музички фолклор, али и сродне дисциплине - театрологија, историја и теорија књижевности, естетика, историја, етнологија и др. Библиотека поседује и многобројне иностране и домаће музичке и музиколошке часописе, нотна издања, грамофонске плоче, компакт-дискове и др. Засебну целину представља архивска збирка с више од две хиљаде докумената, највећим делом везаних за историју српске музике. Институт поседује аутографе композиција српских аутора, преписе, стара и ретка издања и др. Од изузетног је значаја и Фоноархив Института. Да би се ова разноврсна грађа сачувала и учинила доступнијом, године 2006. отпочели су процеси дигитализације. У овом раду биће дат аналитички преглед дигитализације одабране архивске и библиотечке грађе.

Кључне речи: Музиколошки институт САНУ, дигитализација, историја српске музике, музичке библиотеке, музички архиви

Музиколошки институт Српске академије наука и уметности основан је децембра 1947. на иницијативу академика Петра Коњовића (1883-1970), једног од композитора који су у периоду између два светска рата српску музику обогатили тековинама модерних стилова. Широко образован, Коњовић је био и музиколог и музички писац, који је нашу литературу обогатио низом монографија, огледа и превода.

1 Ова студија представља резултат рада на пројекту Музиколошког института САНУ: Идентитети српске музике од локалних до глобалних оквира: традиције, промене, изазови. Пројекат, под бр. 177004, финансира Министарство просвете, науке и технолошког развоја Владе Републике Србије. 
Потребно је да овде, на самом почетку, начинимо привидан искорак из теме и скренемо пажњу на податке који су мало познати у нашим академским круговима. Те податке сасвим ретко и недовољно помиње наша савремена музикологија, а они се непосредно тичу њене историје. А тичу се и Филолошког факултета и његове историје.

Наиме, ретко се помиње чињеница да српска музикологија своје почетке дугује некадашњем Филозофском факултету Београдског универзитета, у ствари данашњем Филолошком факултету. Ујесен 1922. композитор и музиколог Милоје Милојевић (1884-1946), изабран је за асистента за музичке науке на Филозофском факултету у Београду. ${ }^{2}$ По докторирању 1925 . на Карловом универзитету у Прагу, он ће бити унапређен у доцента, касније и у ванредног професора за историју и теорију музике. Филозофски факултет, а нарочито Богдан Поповић који је Милојевића подржавао, показали су свест о томе да је музикологији место међу свим осталим културноисторијским дисциплинама из филозофске и филолошке скупине, поред историје и теорије књижевности и историје уметности. Тим гестом показано је и добро познавање и прихватање праксе европских универзитета, јер у далеко највећем броју европских земаља и тада је музикологија била везана за филозофски факултет, а не за музичке конзерваторијуме и академије на којима се првенствено школују будући композитори, музички извођачи и педагози.

Милојевић није имао самосталне катедре; његов предмет се предавао као изборна, помоћна дисциплина. У организационом погледу, историја музике прво је припадала Семинару за класичну археологију и историју уметности Владимира Петковића, потом Семинару за упоредну књижевност и теорију књижевности Богдана Поповића; по његовом пензионисању, Милојевић је прешао у Српски семинар Павла Поповића и тамо предавао све до 1939. године.

Пре Другог светског рата начињени су покушаји да се отвори Катедра за музичке науке на Филозофском факултету; нажалост, без успеха. После Другог светског рата био је један тренутак колебања и историја музике је обновљена на Филозофском факултету. Међутим, убрзо је превагнуло угледање на совјетски образовни модел, и Кате-

2 О Милојевићу видети у: Васић 2012, Vasić 2013b и Васић 2014. 
дра за историју музике и музички фолклор основана је на Музичкој академији у Београду. Тамо се и данас налазе њене наследнице - Катедра за музикологију и Катедра за етномузикологију.

Напоменимо да се на овај иницијални сегмент историје домаће науке о музици први осврнуо Петар Коњовић, у монографији о Милојевићу (Коњовић 1954). Касније је читав предмет употпуњен реалијама које је пасионирано прикупио и изнео, у два маха, пок. србиста, полониста и компаратиста Ђорђе Живановић (Живановић 1989, 1990).

Једини траг међуратне традиције био је видљив у наставном плану Катедре за општу књижевност и теорију књижевности коју је 1946. обновио професор Војислав Ђурић. Он је историју музике предвидео међу изборним предметима на тој студијској групи. Али на Катедри није било ангажованог наставника за тај предмет. Ако би се неко од студената определио да слуша историју музике, морао би се обратити Музичкој академији.

И поред тога што је музикологија изгубила своје место на Филозофском, односно Филолошком факултету, она је ипак остала присутна, макар само повремено. Један број наших музиколога и музичара своје магистарске и докторске титуле стекао је на Филолошком факултету, на катедрама за општу књижевност и теорију књижевности, за српску књижевност са јужнословенским књижевностима, за библиотекарство и информатику и за славистику. Избором интердисциплинарних, граничних тема, ти стручњаци су своју другу кућу нашли на Филолошком факултету. ${ }^{3}$

Универзитетски почеци наше музикологије нису били праћени формирањем научних института - међуратно раздобље у Југославији није доба института. Систематизација и истраживање музичкофолклорне грађе тада су се одвијали у Етнографском музеју у Београду. Тек после Другог светског рата настаје централна, заједничка научна установа за рад на пољу и музикологије и етномузикологије - Музиколошки институт САНУ.

3 Реч је о следећим музиколозима и музичарима: музички историчар и критичар Слободан Турлаков, музиколог Мирјана Веселиновић-Хофман, пијанисткиња Дубравка Јовичић, музички теоретичар Милован Мишков, музиколог Бранка Радовић, гитариста Урош Дојчиновић, музиколог Александар Васић и пијанисткиња Јасмина Јанковић. У Одељењу за историју Филозофског факултета у Београду докторирала је музиколог Јелена Милојковић-Ђурић. 
Напоредо с почецима научног рада у Музиколошком институту САНУ отпочело је и формирање пратећих јединица Института - библиотеке и својеврсног архива. Од самог почетка постојала је намера да се у Институту формира збирка рукописа, докумената и предмета из српске музичке прошлости. С обзиром на чињеницу да у оно време није постојала - као што ни данас не постоји - институција која би била окренута музеолошкој обради српске музике, требало је у Институту радити на прикупљању, систематизацији и обради споменика наше музичке прошлости.

Пионирска улога у настанку ове колекције припала је Стани Ђурић-Клајн (1908-1986). ${ }^{4}$ Она је започела рад на прикупљању архивског материјала и пресудно је допринела настанку и ширењу овог сегмента Музиколошког института. До повлачења Стане Ђурић-Клајн у пензију колекција је била затвореног типа, а проф. Клајн је колегама и сарадницима из Института и изван њега уступала грађу на коришћење. Доласком академика Димитрија Стефановића на место директора Музиколошког института (1979), архивска колекција је отворена за све категорије корисника. Он је, уз ангажовање научног сарадника др Данице Петровић и спољних сарадника (Слободанка Говедарица, апсолвенткиња археологије, Љиљана Тодић, студенткиња историје уметности, и Слободан Варсаковић, студент музикологије), организовао пописивање и каталогизирање архивске колекције. Такође, од тога времена па до данас, архивска збирка се непрестано увећавала и увећава се. Данас је целокупна архивска грађа у Музиколошком институту пописана и каталогизирана.

Садржај Архива чини око две хиљаде докумената, распоређених у тридесет четири велике архивске кутије. Грађу колекције сачињавају четири основна типа докумената: нотни материјал, литерарна сведочанства, одликовања и други предмети, и фотографије. ${ }^{5}$

4 О Стани Ђурић-Клајн видети у: Васић 2007, Васић 2012. и Vasić 2013.

5 Овде није могућно (а ни неопходно) изнети подробан, већ само сумаран преглед структуре и садржаја Архива Музиколошког института САНУ, како због расположивог простора, тако, пре свега, с обзиром на циљ ове студије - приказ дигитализације. Шира верзија овде изложене структуре Архива дата је у студији Васић 2010. 
Нотни материјал обухвата аутографе композиција српских аутора, преписе, стара и ретка штампана издања, рукописне збирке записа српске народне и црквене музике.

Веома су разноврсна литерарна сведочанства која се налазе у овој збирци. Поред примера музичкотеоријске или уџбеничке литературе, тамо су и рукописи предавања из историје музике, исечци из домаће и иностране штампе у вези с нашим музичарима и њиховим гостовањима у другим срединама и др. Литерарна грађа пружа слику о животу, школовању и каријери српских музичара. У Архиву се налазе и лична документа - крштенице, умрлице, гимназијска сведочанства, универзитетске уписнице и дипломе, семестрални листови, укази о постављењима у државној служби и др. Слици српског музичког и културног живота XIX и XX века, како у Аустроугарској монархији, тако и у Краљевини Србији / Југославији, доприносе и плакати и програми концерата и позоришних представа, затим статути певачких друштава, споменице, путописи.

Збирка од око две стотине фотографија поред индивидуалних фотографија композитора, извођача, музичких писаца, садржи и групне портрете оркестара, хорских и камерних ансамбала, наставника музичких школа и сл. На фотографијама су забележени и значајни музички догађаји, као и ретка издања српске музике.

Првобитно су у састав Архива увођени и појединачни документи и целовите нотне заоставштине српских композитора. Како се број таквих збирки увећао, године 1984. одлучено је да се формира засебан Регистар заоставштина, па се оне од тада уписују као посебна збирка. ${ }^{6}$

У старијој архивској збирци издваја се једанаест већих целина. То су фондови следећих музичара: Корнелија Станковића, Даворина Јенка, Јована Пачуа, Стевана Мокрањца, Исидора Бајића, Теодора-Тоше Андрејевића-Аустралијанца, Станислава Биничког, Владимира Р. Ђорђевића, Петра Крстића, Миленка Пауновића и Косте П. Манојловића.

Корнелије Станковић заступљен је бројним преписима, фотокопијама, али и старим и ретким издањима своје клавирске и вокалне музике. Низ докумената сведочи о музичком раду Даворина

6 О композиторским заоставштинама у Архиву Музиколошког института САНУ видети у: Милановић 2010. 
Јенка. То су нотна издања и преписи, али и фотографије, писма, новински чланци. Фонд Јована Пачуа значајан је за историчаре српске клавирске музике. Институт поседује копије његових Српских звукова, опсежне збирке од дванаест рапсодија за клавир.

Иако се заоставштина Стевана Мокрањца једним делом налази у Архиву Српске академије наука и уметности, и у Музиколошком институту се чува веома значајна нотна грађа овог композитора. Мокрањчева збирка је најобимнија персонална збирка у оквиру архивске колекције Института.

Веома је богата и разноврсна збирка композитора Исидора Бајића, у којој се налази и клавирски извод опере Кнез Иво од Семберије, и то са забелешкама Петра Крстића, као и Бајићева објашњења за ову оперу на мађарском и немачком језику.

У богатије збирке долази и она од Косте П. Манојловића. Поред његових композиција, ту су и другачији извори - рукопис његовог рада о народним попевкама из 1928. године, као и предавање на тему Музички национализам и Корнелије Станковић. Свакако треба истаћи и Манојловићеве анализе Мокрањчевих руковети и Приморских напева.

Велик је број наших музичара XIX и прве половине XX века који су макар и делимично представљени у архивској збирци Института. То су: Владимир Боберић, Никола Ђурковић, Димитрије Големовић, Петар Димић, Јован Иванишевић, Петар Илић, Фрањо Маћејовски, Милоје Милојевић, Сава Селесковић, Јосип Славенски, Велимир Сперњак, Петар Стојановић, Мита Топаловић и многи други.

После Другог светског рата изучавање српске црквене музике изостављено је из наставних планова београдске Музичке академије. То је био данак времену. Академик Петар Коњовић је зато у Музиколошком институту покушао и успео да створи центар за проучавање те, у послератно време идеолошки непожељне музичке области. Деловањем активних сарадника Института, др Димитрија Стефановића и др Данице Петровић (сада у пензији), као и првих асистената Института, пок. др Милоша Велимировића и пок. др Стојана Лазаревића, а у најновије време и др Весне Пено, Институт је постао један од најзначајнијих центара за проучавање православне црквене 
музике у овом делу Европе. Томе доприноси деценијама стварана библиотека литургичких и историографских књига, фотодокументације и звучних записа православне црквене музике, пре свега српске.

Музиколошки институт САНУ поседује и богату етномузиколошку збирку са близу осам хиљада рукописних записа наше народне музике - песама и игара пре свега из Србије, али и из осталих крајева бивше Југославије. Та је колекција од прворазредног научног и културног значаја. О њој постоји прегледна студија етномузиколога мр Ане Матовић, и њој дугујемо податке који следе. ${ }^{7}$

Обимом и значајем издвајају се рукописне збирке записа народних песама и игара Исидора Бајића и Петра Крстића. У Бајићевој заоставштини налази се преко две хиљаде записа народних мелодија, а код Крстића је сачувано више од осам стотина песама и игара. Записи које су оставили ови композитори не потичу само од њих самих; многи су, наиме, преузети од других мелографа (Владимир Р. Ђорђевић, Лудвик Куба /Ludvík Kuba/, Стеван Стојановић Мокрањац, Фрањо Кухач, Тодор Бушетић, Славољуб Лжичар, Корнелије Станковић и др).

Систематски рад на прикупљању и научној обради народних мелодија отпочео је Коста П. Манојловић. На његову иницијативу основано је 1923. у београдском Етнографском музеју Одељење за музички фолклор, у којем је формирана и прва фонографска збирка народних мелодија у Србији. У Музиколошком институту САНУ налази се целокупна, дакле та наша прва збирка записа музичког фолклора. Материјал обухвата више од хиљаду песама и игара. Највећи део је из Јужне Србије, Македоније и с Косова, и потиче од Косте П. Манојловића, али има записа и из других крајева бивше Југославије.

Годину дана по оснивању Музичке академије у Београду (1937), Коста П. Манојловић покушао је да створи архив целокупног, до оног времена сакупљеног музичког фолклора код нас. Сав тај материјал пренет је 1948. у Музиколошки институт. Тај фонд, чије је обликовање започето на Музичкој академији, а настављено у Музиколошком институту, обухвата седам збирки народних мелодија.

7 Видети: Матовић 1973. 
После Етнографског музеја и Музичке академије, трећи центар за сакупљање народне музике био је Радио Београд. У Музиколошком институту налазе се и две збирке песама из Архива Радија. То су: записи песама с острва Хвара и „Преписани народни мотиви из Радио Београда“. Ова збирка садржи преко стотину мелодија из разних крајева Југославије.

Музиколошки институт је и откупљивао рукописне збирке народних мелодија. До 1973. откупљено је дванаест таквих збирки. Било је и дародаваца. Поједине збирке народних мелодија Институту су поклонили Светомир Настасијевић, Лајош Киш (Lajos Kiss), Ернест Дијамант (Ernest Diamant) и др. The Chamber Music Society поклонило је збирку With the Serbs 1916-1918. Лајонела Бадена (Lionel Budden). Збирка садржи песме и игре забележене за време Првог светског рата према певању српских војника смештених у пољској болници у Вертепу, у близини Солуна.

Пажњу скрећемо и на последњу објављену етномузиколошку збирку. У питању је у новије време откупљена збирка Саве Л. Илића, Музичко наслеђе Срба, Шокаца и Карашеваца у Румунији, коју је за штампу приредила етномузиколог др Јелена Јовановић, научна сарадница Института, а објављена је 2006. као заједничко издање Матице српске и Музиколошког института.

По природи ствари, у колекцији Института мање су заступљени домаћи композитори друге половине XX века. Ипак, постоје у преписима или штампаним издањима дела Петра Бингулца, Михаила Вукдраговића, Миховила Логара, Владе Милошевића, Златана Вауде и других композитора. Од савремених дела свакако треба указати на оригиналну партитуру опере Симонида Станојла Рајичића, коју је Институту поклонила композиторова удовица, професорка Милица Рајичић.

Јужнословенска музика сразмерно је мало заступљена. То је и логично, с обзиром на чињеницу да у Загребу, Љубљани, Сарајеву, Скопљу и другим градовима бивше југословенске федерације, постоје научни институти и архиви које су се у заједничкој држави бавили прикупљањем и обрадом националне музике. У Музиколошком 
институту САНУ налазе се литографије, штампана издања и преписи композиција словеначких аутора: Емила и Карла Адамича, Франца Берника, Фрање Вилхара (старијег), Јанка Грегорца, Бењамина Ипавца, Марија Когоја, Винка Крека, Антона Лајовица, Луцијана Марије Шкерјанца и др. Хрватску музику представљају композиције и хармонизације Благоја Берсе, Силвија Бомбарделија, Винка Жганеца, Ивана Зајца, Јакова Готовца, Антуна Добронића, Фрање Дугана, Вјекослава Клаића, Фрање Ксавера Кухача, Ватрослава Лисинског, Ивана Матетића-Роњгова, Иве Параћа и др.

Европска музика заузима у архивским збиркама Музиколошког института још мање места него јужнословенска. Као одраз оријентације и уметничког нивоа српске музике у XIX веку, у Институт су стигла штампана издања старије европске салонске музике. Углавном су то албуми с композицијама разних аутора који су у своје време уживали популарност шире музичке публике (Л. Ардити, Т. Бадажевска, Л. Г. Ган, Д. Херценбергер, К. J. А. Целер, Х. Шмит / L. Arditti, Tekla Badarzewska, LouisGaston Ganne, D. Herzenberger, Carl Johann Adam Zeller, H. Schmidt и др.) Студијама српске црквене музике могу помоћи примери руске црквене музике сакупљани у архивској колекцији, али и у библиотеци и нототеци Студијског хора. Тамо се налазе композиције Аренског (Антон Степанович Аренский), Бортњанског (Дмитрий Степанович Бортнянский), Глазунова (Александр Константинович Глазунов), Рахмањинова (Сергей Васильевич Рахманинов), Чеснокова (Павел Григорьевич Чесноков) и других композитора.

Засебну целину чине мешовити албуми са српском, јужнословенском и европском музиком. Таквих албума има близу тридесет. Грађа окупљена у њима широког је спектра: српске народне песме и игре у обрадама за клавир, руске и хрватске народне песме, духовна музика, војна музика итд. Ти су албуми аутентична слика музичких потреба и навика грађанске епохе XIX и прве половине XX века. У ондашњим домовима певала се и свирала, поред народне, и салонска музика, страна и домаћа; тако се проводило слободно време и њоме је био обележен друштвени живот. ${ }^{8}$

8 На овој архивској грађи Музиколошког института САНУ засноване су, значајним делом, монографије о српској клавирској музици старијег времена (Јеремић-Молнар 2006; Кокановић Марковић 2014). 
Збирка од преко две стотине фотографија представља изузетно вредан сегмент архивске колекције Музиколошког института. Фотографије појединих старијих српских музичара није увек лако наћи у другим установама, што нарочито долази до изражаја у текућем раду на Српском биографском речнику Матице српске, као и на другим енциклопедијама и лексиконима који желе да објаве слике одређених личности. У Институту постоје фотографије бројних старијих музичара: Славке-Алојзије Атанасијевић, Теодора-Тоше Андрејевића-Аустралијанца и његове супруге Ивлин (Evelyn), Исидора Бајића, Станислава Биничког, Ивана Брезовшека, Хуга Доубека, Владимира Р. Ђорђевића, Николе Ђурковића, Јована Иванишевића, Душана Јанковића, Даворина Јенка, Алојза Калауза, Драгомира Кранчевића, Аксентија Максимовића, Косте П. Манојловића, Јосифа Маринковића, Милана Миловука, Стевана Мокрањца, Тихомира Остојића, Миленка Пауновића, Јована Пачуа, Јованке Стојковић, Роберта Толингера, Мите Топаловића, Јосифа Шлезингера и др. Заступљене су и фотографије новијих музичара, не само српских: Златко Балоковић, Јован Бандур, Радмила Бакочевић, Миодраг Васиљевић, Михаило Вукдраговић, Мирјана Вукдраговић, Војислав Вучковић, Миленко Живковић, Живојин Здравковић, Зденка Зикова, Љубица Марић, Ловро Матачић, Анита Мезетова, Милоје Милојевић, Предраг Милошевић, сестре Олга и Марија Михаиловић, Василије Мокрањац, Бахрија Нури-Хаџић, Марко Тајчевић и др.

Библиотека Института једна је од најзначајнијих у својој врсти на територији Србије. Она поседује преко 10.000 књига на српском и великом броју страних језика. Највећим делом реч је о литератури из области музикологије и етномузикологије, али и читавог низа граничних дисциплина (наука о књижевности, историја, етнологија, богословија, историја уметности, театрологија, естетика и др). Посебно је значајан фонд домаће и иностране музичке периодике. Партитуре музичких дела, српских и иностраних композитора, грамофонске плоче, компакт-дискови класичне музике, употпуњују слику набављане библио- 
течке грађе. Како је већ поменуто, Институт је један од најзначајнијих центара за музичку византологију у овом делу Европе, па је литература о средњовековној музици обилно заступљена. ${ }^{9}$

Прелазећи на актуелни тренутак, долазимо до дигитализације музиколошке и етномузиколошке грађе у Музиколошком институту.

Одавно је препознато да је дигитализација најбољи начин очувања и презентације архивске и раритетне библиотечке грађе. Услови за отпочињање тих активности у Музиколошком институту САНУ стекли су се 2006. године, и то најпре у сфери етномузикологије. Руководилац тог пројекта био је др Растко Јаковљевић, а сарадници етномузиколози из Института и спољни сарадници. Изузетно је значајан овај рад др Јаковљевића на дигитализацији Фоноархива Института, на првом месту воштаних плоча и жичаних калемова, али и магнетофонских трака. Та грађа представља велику драгоценост. Део активности дигитализације тог материјала одвијао се у сарадњи с водећим установама у иностранству (Phonogrammarchiv - Институт за аудиовизуелна истраживања и документацију Аустријске академије наука у Бечу, Мађарска академија наука). ${ }^{10}$

Музиколошки институт никада није имао, а тако је и данас, стручног библиотекара који би се бринуо о чувању, обради и издавању библиотечке и архивске грађе Института. Како се том проблему не назире решење, а с обзиром на потребе за, пре свега, очувањем грађе, то се приспело до идеје да се сарадници Института ангажују на пројектима изван својих редовних радних обавеза на основном научном пројекту Института. Могућности су се отвориле кроз конкурсе републичког Министарства културе и информисања и Секретаријата за културу града Београда.

Године 2011. отпочео је пројекат Музиколошког института САНУ, Каталогизација и дигитализација архивске грађе Музиколошког института САНУ. Руководиоци су били музиколог др Катарина Томашевић и етномузиколог др Данка Лајић-Михајловић. На почетку рада на овом пројекту постављена је дугорочна стратегија систематског

9 О Библиотеци Института видети у: Милин 2010.

10 О раду на дигитализацији Фоноархива Музиколошког института САНУ видети у: Јаковљевић 2014. 
рада на, како су формулисале др Томашевић и др Лајић-Михајловић, примарној обради, попису, ревизији, техничкој заштити, каталогизацији и дигитализацији архивске грађе Музиколошког института САНУ.

Током 2011. године обављени су претходни послови - претходни у односу на дигитализацију. У области уметничке музике били су то ревизија и електронска каталогизација појединих фондова рукописне, углавном нотне архивске грађе (Стеван Мокрањац, Ненад Барачки, Петар Коњовић), као и делимичан попис заоставштине композитора и диригента Светолика Пашћана. Од ретких штампаних музичких издања електронски је пописана Српска музичка библиотека композитора Исидора Бајића. Године 2011. Музиколошки институт САНУ није располагао ваљаним техничким средствима, па је скенирање одабране архивске грађе урађено у сарадњи с издавачком кућом „Службени гласник“.

У области фолклорне музике био је извршен попис рукописних мелографских збирки и теренских бележница значајних истраживача музичког фолклора (Милица Илијин, Петар Крстић, Исидор Бајић), анкетног материјала који су тридесетих година XX века прикупили стручњаци из Етнографског музеја у Београду, као и попис рукописне нотно-текстуалне збирке скадарлијског певача Љубомира Петковића, настале шездесетих година XX века - то је садржај који се убраја у тзв. новију традицију народне музике.

Примерена техничка опрема стигла је у Музиколошки институт САНУ крајем 2011. године. Тиме је омогућен настанак дигиталног архива Института.

Међутим, једној повољности нашкодила је једна невоља. Наиме, током наредне, 2012. године, од државе су одобрена знатно умањена новчана средства, па је то преполовило ангажман стручњака и број резултата. Ипак, резултати нису изостали. Скенирани су аутографи Стевана Мокрањца, поједини преписи његових дела и архивска докумената значајна за проучавање његовог опуса. А у области фолклора скениране су поменуте мелографске збирке и теренске бележнице Милице Илијин, Петра Крстића и Исидора Бајића.

Током треће године пројекта (2013), апсолвирани су неколики задаци. Извршени су етномузиколошко-архивска обрада и делимично скенирање заоставштине етномузиколога Радмиле Петровић, 
дугогодишње сараднице Института. Основну обраду (попис и физичка заштита) добио је и део заоставштине етнокореолога Милице Илијин, откривен у заоставштини Р. Петровић. Пажња је била управљена и на један део оставштине Љубице и Данице Јанковић, пионирки етнокореологије у Србији (попис). Др К. Томашевић се определила за дигитализацију дела рукописне нотне заоставштине композитора Петра Коњовића и збирке нотних албума с композицијама насталим У другој половини XIX века, као и за заоставштину композитора и музиколога Драгутина Гостушког, пионира упоредне естетике у Србији (прва фаза рада: преглед, класификација, заштита).

Претпрошле године рад на пројекту био је обустављен због ускрате финансијских средстава. Међутим, те године је Министарство културе и информисања Србије финансирало пројекат конзервације старе и ретке рукописне и штампане књиге у поседу Музиколошког института САНУ. Руководилац пројекта била је др Весна Пено, виша научна сарадница Музиколошког института САНУ, а носиоци пројекта били су Институт и Народна библиотека Србије.

Године 2015. Секретаријат за културу града Београда прихватио је пројекат дигитализације београдске међуратне музичке периодике. Под руководством др Александра Васића урађена је интегрална дигитализација „Звука“ (1932-1936), најзначајнијег музичког часописа на подручју Србије и бивше Југославије у међуратном раздобљу. ${ }^{11}$ Институт је једина установа у земљи која располаже комплетом српске музичке периодике до 1941. године. Др Данка Лајић-Михајловић је руководила пројектом дигитализације записа народних мелодија из заоставштине Косте П. Манојловића. Тај пројекат су заједнички финансирали Министарство културе и информисања Србије и Секретаријат за културу града Београда.

Додајмо да је рад на дигитализацији био основа за настанак неколиких научних студија и прилога Катарине Томашевић, Јелене Јовановић, Растка Јаковљевића, Марије Думнић и Данке ЛајићМихајловић. ${ }^{12}$

11 О часопису „Звук“ видети у Васић 2012 (и тамо наведену литературу), као и Васић 2013а.

12 Видети: Tomašević 2003; Jovanović - Jakovljević 2008; Думнић 2010; Думнић Јаковљевић 2014; Думнић - Лајић-Михајловић 2014; Лајић-Михајловић - Јовановић 2014; Лајић-Михајловић - Думнић 2015. 
Овај преглед рада на дигитализацији у Музиколошком институту САНУ сведочи о свести и иницијативи научника, сарадника Института, да се отпочне с пословима који представљају не само будућност већ и, увелико, садашњост, када је реч о заштити ретке и вредне архивске и библиотечке грађе. Кадровско појачање, а нарочито материјално обезбеђење оваквих пројеката услови су чије ће испуњење убрзати темпо њиховог извођења и подићи ниво аспирације.

\section{Листа референци}

Васић, Александар (2007), „Ђурић-Клајн, Стана“, у: Српски биографски речник, књ. 3, Нови Сад: Матица српска, 662-663.

Васић, Александар (2010), „Архив Музиколошког института САНУ“, Музикологија 10: 71-85 (на енглеском, у преводу Ранке Гашић: 86-100).

Васић, Александар (2012), Српска музикографија међуратног доба у огледалу корпуса музичке периодике, докторска дисертација одбрањена на Академији уметности Универзитета у Новом Саду; Библиотека Матице српске у Новом Саду, сигн. D 5720.

Vasić, Aleksandar (2013), „Djurić-Klajn, Stana“, in: The Grove Music Online: www. oxfordmusiconline.com.

Васић, Александар (2013a), „'Материјалисти' и 'идеалисти' у нетраженом дијалогу: часопис Звук (1932-1936) и музика Западне Европе“, Музикологија 14: 77-92.

Vasić, Aleksandar (2013b), „Milojević, Miloje“, in: The Grove Music Online: www. oxfordmusiconline.com.

Васић, Александар (2014), „Милојевић, Милоје“, у: Српски биографски речник, књ. 6, Нови Сад: Матица српска, 590-594.

Думнић, Марија (2010), „Project Digitization and Catalogization of Phonoarchive of the Institute of Musicology SASA: Experiences and Perspectives", Review of the National Center for Digitization 17, Belgrade: Faculty of Mathematics, 39-44. (http://www.ncd.matf.bg.ac.rs/casopis/17/ NCD17039.pdf).

Думнић, Марија - Јаковљевић, Растко (2014), „Дигитализација грађе фоноархива Музиколошког институа САНУ“, у Растко Јаковљевић (ур.), Фоноархив Музиколошког института САНУ: историјски звучни записи у дигиталној ери, Београд: Музиколошки институт САНУ, 13-25.

Думнић, Марија - Лајић-Михајловић, Данка (2014), „Институционализација етнокореологије у Србији: заоставштина Љубице Јанковић у Музиколошком институту САНУ“, Музикологија 17: 259-272.

Đurić-Klajn, Stana (1981), Akordi prošlosti, Beograd: Prosveta. 
Живановић, Ђорђе (1989), „Напомене о једној споменици. Двадесет пет година од изласка споменице Сто година Филозофског факултета“, Прилози за књижевност, језик, историју и фолклор, књ. 53-54, св. 1-4 (1987-1988): 228-247.

Живановић, Ђорђе (1990), „Милоје Милојевић - професор Филозофског факултета у Београду, Зборник Матице српске за сценске уметности и музику 6-7: 325-348.

Јаковљевић, Растко (ур.) (2014), Фоноархив Музиколошког института САНУ: историјски звучни записи у дигиталној ери, Београд: Музиколошки институт САНУ.

Јеремић-Молнар, Драгана (2006), Српска клавирска музика у доба романтизма (1841-1914), Нови Сад: Матица српска.

Jovanović, Jelena - Jakovljević, Rastko (2008), „Challenges and Developments in Digitization project in the Institute of Musicology SASA, Belgrade", in: Technical Challenges and Developments in 21st Century Folk Music Archiving, Institute for Musicology-Hungarian Academy of Sciences, у електронској форми на вебсајту Мађарске академије наука: http://www.zti.hu/archivum/konferencia_2008/ belgrade.pdf.

Кокановић Марковић, Маријана (2014), Друштвена улога салонске музике у животу и систему вредности српског грађанства у 19. веку, Београд: Музиколошки институт САНУ.

Коњовић Петар (1954), Милоје Милојевић, композитор и музички писац, Београд: Српска академија наука.

Лајић-Михајловић, Данка (2010), „Фоно збирка Музиколошког института САНУ“, Музикологија 10: 141-146 (на енглеском, у преводу Јелене Симоновић-Шиф: 147-151).

Лајић Михајловић, Данка - Думнић, Думнић (2015), „Удружења фолклориста као подстицај интердисциплинарности: искуства етномузикологије са Савезом удружења фолклориста Југославије”, у: Смиљана Ђорђевић Белић, Данка Лајић Михајловић, Немања Радуловић, Бошко Сувајџић, Ђурђина Трубарац Матић (ур.), Савремена српска фолклористика 2, Београд: Институт за књижевност и уметност, Удружење фолклориста Србије, Универзитетска библиотека „Светозар Марковић”, 109-128 (http://ufs.rs/dokumenta/ zbornici/ssfii.pdf).

Лајић-Михајловић, Данка - Јовановић, Јелена (2014), „Историјат сакупљања теренских звучних записа традиционалне музике у Музиколошком институту САНУ“, у: Растко Јаковљевић (ур.), Фоноархив Музиколошког института САНУ: историјски звучни записи у дигиталној ери, Београд: Музиколошки институт САНУ, 2-12.

Матовић, Ана (1973), „Рукописне збирке народних мелодија у Музиколошком институту“, у: Српска музика кроз векове, Београд: Галерија САНУ, 293-313.

Милановић, Биљана (2010), „Фонд композиторских заоставштина у Музиколошком институту САНУ“, Музикологија 10: 101-119 (на енглеском: 120-139). 
Милин, Мелита (2010), „Библиотека Музиколошког института САНУ“, Музикологија 10: 59-64 (на енглеском, у преводу Биљане Грујовић: 65-70).

Mosusova, Nadežda (1990), ,The Importance of the Archives of the Belgrade Musicological Institute in Historical Research into Musical Theatre", Theatre Collections and the Public, Mannheim: SIBMAS Congress, 160-163.

Пено, Весна (2010), „Микрофилмови и фотографије неумских рукописа у Архиву Музиколошког института САНУ“, Музикологија 10: 153-163 (на енглеском, у преводу Биљане Грујовић: 164-174).

Tomašević, Katarina (2003), „Značaj digitalizacije muzikalija i zvučnih zapisa u Arhivu i Fonoteci Muzikološkog instituta SANU“, Pregled Nacionalnog centra za digitalizaciju 2: 46-51.

\section{Aleksandar Vasić \\ Institute of Musicology SASA}

\section{DIGITAL MUSICOLOGY}

\section{Summary}

The Institute of Musicology of the Serbian Academy of Sciences and Arts in Belgrade was founded in 1947. It is the first and oldest institution of its kind in Serbia and the former Yugoslavia. From the beginning, the Institute was conceived as a central place for musicological and ethnomusicological research in Serbia, so gradually library and archives were formed as ancillary units. The Institute has more than ten thousand books. Their thematic range is voluminous the history and theory of music, church music, musical folklore, and related disciplines - theatre history, history and theory of literature, aesthetics, history, ethnology etc. The library has a great number of domestic and international musical and musicological journals, musical scores, records, compact discs etc.

Separate entity presents archives with more than two thousand documents, mostly related to the history of Serbian music: musical materials, literary certificates, medals, photographs. The Institute has autographs of Serbian composers, transcripts, old and rare editions etc.

The library and archives collection of the Institute belongs to the richest and most valuable collections of its kind in the country. In order to preserve this material and make it accessible, in 2011 began the process of digitization.

Key words: Institute of Musicology - Serbian Academy of Sciences and Arts, digitization, history of Serbian music, musical libraries, musical archives 